Our Nature (2008) 6: 82-83

\title{
Freshwater Molluscs from Mudbalwa Village Develoment Committee, Rautahat, Nepal
}

\author{
C.N.R Yadav ${ }^{1}$ and B.R. Subba ${ }^{2}$

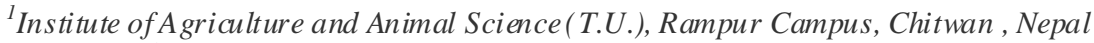 \\ ${ }^{2}$ Department of Zoology, P.G. Campus, Biratnagar, T.U., Nepal
}

Received: 12.08.2008, Accepted: 22.10.2008

Keywords: Mollusc, Mudbalwa VDC, Nepal

Little attention has been paid to the molluscan diversity and its importance in Nepal. Limited contributions have been made on molluscs of Nepal, in spite of its richness. Fragmentary reports on molluscs of Nepal encompass the contributions of Schileyko and Kunznetsov (1996), Kuznetsov (1996), Kuznetsov and Schileyko (1997), Subba and Ghosh (2000, 2001, 2008), Subba (2003), Nesemann and Sharma (2003), Surana et al., (2004). Subba and Pandey (2005), Subba and Ghosh (2008). Molluscan samples were collected from local fish ponds of Mudbalwa village Development Committee (VDC), Rautahat (N 26 $44^{\prime}-27^{\circ} 14^{\prime}$ and E 85 $14^{\circ}$ $85^{\circ} 30^{\prime}$ ) with the help of scoop net and cast net. Hand picking technique was frequently applied in the collection. The collected dry shells were thoroughly cleaned with the help of soft toothbrush and waterthen left for a day in the sun to dry andkept in plastic containers. Live specimens were preserved in $70 \%$ alcohol and some in $5 \%$ formalin for further study. Identification of the specimens was done with the help of Subba Rao (1989) and other available literat ure.
The collection comprised nine of molluscs belonging to six families viz. Viviparidae, Pilidae, Planorbidae, Thiaridae, Amblemidae and Corbilidae. Out of six families, two families viz. Thiaridae and Amblemidae are represented by two species (Table 1). No representation of Lymnaedae was found in the collection time. The population of Bellamya crassa and Thiara fabirculasa was comparatively more than that of other species. In the same time Bellamya crassa has not been reported from any parts of Nepal yet.

\section{Ackn owle dgements}

Authors are very much thankful to local people of Mudbalwa VDC, Rautahat for their generous help during the survey of molluscs.

\section{Refe rences}

Kuznetsov, A.G. 1996, Himalodiscus aculeatus Kuznetxov, et. sp, Nov, (Pulmonata, Endodontidae) from Nepal . Ruthenica 5(2): 163-165.

Schileyko, A.A. and A.G. Kunznetsov. 1996. A new genur of the subulinidae (Pulmonata) from 


\section{C.N.R. Yadav and B.R. Subba / Our Nature (2008) 6: 82-83}

Nepal. Ruthenica 5(2): 158-160.

Kuznetsov, A.G. and A.A. Schileyko. 1997. New data on Enidae (Gastropoda, Pulmonata) of Nepal. Ruthenica 7(2): 133-140.

Nesemann, H. and S. Sharma, 2003. Population dynamics and distribution of the aquatic molluscs (Gastropods, Bivalvia) from Nepal. Paper presented at the international conference on Himalayan Biodiversity, Kathmandu, Nepal .

Subba, B.R. 2003. Molluscan checked list of Ghodaghodi Tal Area, Kailali district. Our Nature (1): 1-2.

Subba, B.R. and T.K. Ghosh 2000. Some freshwater molluscs from eastem and central Nepal. J.Bombay Nat.Hist.Soc.97 (3): 452-455.
Subba, B.R. and T.K. Ghosh 2001.Land molluscs from eastern and central Nepal. J.Bombay Nat.Hist.Soc97 (4):58-61.

Subba, B.R. and T.K. Ghosh 2008 Report on some terrestrial molluscs from different regions of Nepal .J.Nat Mus (23): 78-81.

Subba, B.R and M.R Pandey 2005. Molluscan diversity of Jhapa district. Eastem Nepal. J.Nat. Hist. Mus. (22): 22-27.

Subba Rao, N.V.1989. Handbook of freshwater Molluses of India. Zoological Survey of India, Calcutta ,pp 289.

Surana, R., B.R .Subba. and K P.Limbu 2004. Report of Molluscs from Chimdi Lake (Birju tal), Sunsari district Nepal.Our Nature (2): 45-46.

Table 1 List of molluscin Mudbalwa VDC

\begin{tabular}{|l|l|}
\hline Family & Scientific name \\
\hline Viviparidae & $\begin{array}{l}\text { Bellamya bengalensis f. typica (Lamarck, 1882) } \\
\text { Bellamya crassa (Benson 1836) }\end{array}$ \\
\hline Pilidae & Pila globosa (Swainson) \\
\hline Planorbidae & Indoplanorbis exutus (Deshasyes) \\
\hline Thiaridae & $\begin{array}{l}\text { Thiara tuberculata (Mueller, 1774) } \\
\text { Brotia (Antimelania) costula (Rafinesque, 1833) }\end{array}$ \\
\hline Amblemidae & $\begin{array}{l}\text { Parreysia favidens (Lea, 1831) } \\
\text { Lamellidens marginalis (Lamarck,1819) }\end{array}$ \\
\hline Corbilidae & Corbicula striatella (Deshayes, 1854) \\
\hline
\end{tabular}

